\title{
Effect of Nitrogen and Potassium on Growth, Yield and Quality of Orange Fleshed Sweet Potato (Ipomoea batatas Lam.)
}

\author{
S. R. Sharath ${ }^{1 *}$, M. Janaki ${ }^{2}$, K. Uma Jyothi ${ }^{3}$ and K. Uma Krishna ${ }^{3}$ \\ ${ }^{1}$ Department of Horticulture with Specialization in vegetable science, \\ College of Horticulture, Venkataramannagudem, India \\ ${ }^{2}$ Horticultural Research Station, Peddapuram, India \\ ${ }^{3}$ College of Horticulture, Venkataramannagudem, India \\ *Corresponding author
}

\section{A B S T R A C T}

\section{Keywords}

Orange fleshed sweet potato, nitrogen, potassium, growth, yield, quality.

Article Info

Accepted:

05 February 2020

Available Online:

10 March 2020
An experiment was conducted entitled Effect of nitrogen and potassium on growth, yield and quality of orange fleshed sweet potato (Ipomoea batatas Lam.) was carried out during the rabi season, 2018-2019 at Horticultural Research Station, Peddapuram, East Godavari District of Andhra Pradesh. The study was carried out with 4 levels of nitrogen and potassium and was laid out in a factorial randomized block design (FRBD). The different levels of nitrogen had significant influence on the plant growth parameters, yield parameters and quality parameters. The soil application with $120 \mathrm{~kg} \mathrm{~N} \mathrm{ha}^{-1}$ has recorded highest values for all the studied parameters except starch and reducing sugars. While the highest starch and reducing sugars were found with application of $30 \mathrm{~kg} \mathrm{~N} \mathrm{ha}^{-1}$ and $90 \mathrm{~kg}$ $\mathrm{N} \mathrm{ha}^{-1}$ respectively. The influence of different levels of potassium on all the studied parameters was significant except reducing sugars and recorded the maximum values with the application of $120 \mathrm{~kg} \mathrm{~K} \mathrm{ha}^{-1}$. The nitrogen and potassium interaction effects were nonsignificant for most of the parameters except for vine length at final harvest, number of branches per vine, number of leaves per vine at 90 DAP \& at final harvest, total leaf area per vine at all growth stages, root tuber girth, root tuber yield per vine, root tuber yield per plot, estimated root tuber yield per hectare, beta carotene, starch which were differed significantly. The maximum values for all significantly differed parameters were found with application of $120 \mathrm{~kg} \mathrm{~N} \mathrm{ha}^{-1}$ and $120 \mathrm{~kg} \mathrm{~K} \mathrm{ha}^{-1}$. Among the different treatment combinations, it was found that the treatment combination of nitrogen at $120 \mathrm{~kg} \mathrm{ha}^{-1}$ and potassium at $120 \mathrm{~kg} \mathrm{ha}^{-1}\left(\mathrm{~T}_{16}\right)$ proved to be the best for cultivation of orange fleshed sweet potato.

\section{Introduction}

Sweet potato (Ipomoea batatas Lam.) is an important tuber crop grown in the tropics, sub-tropics and warm temperate regions of the world for its edible storage roots. It is a herbaceous and perennial vine cultivated as an annual. It belongs to family convolvulaceae and originated from Central America. It is a cross-pollinated, hexaploid vine $(2 n=6 X=90)$ (Jones, 1965). In India it is popularly known as 'Sakarkand'. Sweet 
potato is vegetatively propagated crop through vine cuttings and it is rich in several essential macro and micro nutrients. It is excellent source of complex carbohydrates, high antioxidants, vitamins, phosphorus, potassium, magnesium, calcium, sulphur, iron, manganese, copper, boron, zinc, iodine, folic acid, fiber, starch and protein.

The starch in sweet potato easily converts to sugar and provides quick energy. The roots are used as a source of starch, glucose, sugar syrup, industrial alcohol, dietary fibre and also used to feed livestock. Dietary fibre has the potential to reduce the incidence of a variety of diseases in man including colon cancer, diabetes, heart diseases and digestive disturbances. The flesh colour of the root varies from various shades of white, cream, yellow to dark-orange depending upon the carotenoid content. $\beta$-carotene is the major carotenoid present in orange fleshed sweet potato which is a precursor of vitamin A.

Keeping above in view, the hybrid PSP-1 (pre released orange fleshed hybrid) have been developed by crossing Bhu Sona (orange fleshed) with Kalinga (white fleshed) at HRS, Peddapuram. The PSP-1showed optimum tuber yield with pink skin colour, dark orange flesh colour, high carotene, high starch content and high sugar content.

Now-a-days, the nutrient pool present in soil is depleted to such an abnormal level which is unable to supplement nutrients required to maintain soil health. In absence of soil test support, imbalanced use of fertilizers was often observed. Sweet potato produces more dry matter per unit area per unit time compared to cereals. This high rate of dry matter production results in large amount of nutrient removal per unit time and most of soils are unable to meet the demand. Hence, use of chemical fertilizers is considered as a key factor in realizing higher sweet potato production. Its production depends on many factors. Among them, judicious application of nitrogen and potassium plays an important role.

Nitrogen is most important major plant nutrient and it helps for growth and development of crop. It has absorb in the form of ions $\left(\mathrm{NH}_{4}{ }^{+}\right.$and $\left.\mathrm{NO}_{3}{ }^{-}\right)$through the roots or leaves and incorporate it in organic matter throughout the whole growing season by transfer the mineral into a organic form. It is attributed to the role as one of the most important macronutrient for yield and quality of vegetables. The nitrogenous fertilizers (rates and sources) have remarkable influences on roots, tops and sugar yields as well as chemical composition and root quality (TSS\%, sucrose \% and juice purity) (Selim et al., 2010).

Potassium is one of the most essential nutrient required for plant development. It plays vital role in several physiological processes such as photosynthesis, translocation of photosynthates, control of ionic balance, regulation of plant stomata and transpiration, activation of plant enzymes and many other processes. Potassium also enhances $\mathrm{N}$ uptake and protein synthesis resulting better foliage growth. Beside this, it also increases water use efficiency.

Combine application of $\mathrm{N}$ and $\mathrm{K}$ increases foliage and leaf area index (Marton, 2010). It plays a major role in the production of root tubers. Hence, it is necessary for enhancing the root tuber yield and yield attributes. It is also evident from the literature that sweet potato growth and yield responds positively to nitrogen and potassium. To improve the yield and quality of sweet potato, there is a need to standardize the optimum dose of nutrients for improving the physio-chemical properties of soil as well as yield and quality of produce. 


\section{Materials and Methods}

An experiment was conducted in college of horticulture, Venkataramannagudem during the rabi season, 2018-2019. This experiment was laid out in factorial randomized block design with 3 replications and 16 treatments with the spacing of $60 \times 20 \mathrm{~cm}^{2}$. Two factors include 4 levels of nitrogen $\left[30\left(\mathrm{~N}_{1}\right), 60\left(\mathrm{~N}_{2}\right)\right.$, 90( $\left(\mathrm{N}_{3}\right)$ and $\left.120\left(\mathrm{~N}_{4}\right) \mathrm{kg} \mathrm{ha}^{-1}\right]$ and potassium [30 $\left(\mathrm{K}_{1}\right), 60\left(\mathrm{~K}_{2}\right), 90\left(\mathrm{~K}_{3}\right)$ and $\left.120\left(\mathrm{~K}_{4}\right) \mathrm{kg} \mathrm{ha}^{-1}\right]$. Graded levels of nitrogen and potassium was split in to half at time of planting and reaming half at the 30 days after planting and recommended dose of phosphorous was applied in the same time.

Random selection of five plants per plots for recorded the growth, yield and quality characters like vine length, number of branches per vine, number of leaves per vine and total leaf area per vine; yield parameters number of root tubers per vine, root tuber length, root tuber girth, vine dry matter content, root tuber dry matter content, root tuber yield per vine, root tuber yield per plot and estimated root tuber yield per hectare \& quality parameters like beta carotene, starch, reducing sugars, non-reducing sugars and total sugars were recorded at the harvesting stage of sweet potato. Data recorded on growth, yield and quality parameter was subjected to analysis of variance (ANOVA, $p$ $\leq 0.05$ ) and means comparisons were done at $P \leq 0.05$.

\section{Results and Discussion}

\section{Growth parameters}

The data on the effect of different levels of nitrogen, potassium and their interactions on vine length, number of branches per vine, number of leaves per vine and total leaf area per vine were recorded at final harvest.

\section{Vine length $(\mathrm{cm})$}

The data on the effect of different levels of nitrogen, potassium and their interactions on vine length has recorded at final harvest are rendered in table1.The vine length increased with increasing levels of nitrogen at final harvest showing the maximum of $193.08 \mathrm{~cm}$ with application of $120 \mathrm{~kg} \mathrm{~N} \mathrm{ha}^{-1}$, which was followed by $90 \mathrm{~kg} \mathrm{~N} \mathrm{ha}{ }^{-1}$. The minimum vine length of $133.05 \mathrm{~cm}$ was recorded when crop applied with $30 \mathrm{~kg} \mathrm{~N} \mathrm{ha}^{-1}$ at final harvest.

The potassium application at $120 \mathrm{~kg} \mathrm{~K}^{-1}$ recorded maximum vine length of $171.59 \mathrm{~cm}$ (at final harvest) and the minimum vine length of $152.28 \mathrm{~cm}$ was obtained with the application of $30 \mathrm{~kg} \mathrm{~K} \mathrm{ha}^{-1}$ at final harvest respectively.

Among the interaction effects, the treatment combination $120 \mathrm{~kg} \mathrm{~N}+120 \mathrm{~kg} \mathrm{~K} \mathrm{ha}^{-1}$ has recorded maximum vine length of $216.73 \mathrm{~cm}$ at final harvest and the minimum vine length was recorded with $30 \mathrm{~kg} \mathrm{~N}+30 \mathrm{~kg} \mathrm{~K} \mathrm{ha}$ ${ }^{1}$ with $127.67 \mathrm{~cm}$ at final harvest.

\section{Number of branches per vine}

The data on the effect of different levels of nitrogen, potassium and their interactions on number of branches per vine has recorded at final harvest are rendered in table 1.In respect of different levels of nitrogen, the number of branches per vine increased with increasing levels of nitrogen at final harvest showing the maximum of 14.93 branches with the application of $120 \mathrm{~kg} \mathrm{~N} \mathrm{ha}^{-1}\left(\mathrm{~N}_{4}\right)$, which was followed by $90 \mathrm{~kg} \mathrm{~N} \mathrm{ha}^{-1}\left(\mathrm{~N}_{3}\right)$. The minimum number of branches was recorded when crop applied with $30 \mathrm{~kg} \mathrm{~N} \mathrm{ha}^{-1}\left(\mathrm{~N}_{1}\right)$ at final harvest (7.88).

The potassium application at $120 \mathrm{~kg} \mathrm{~K} \mathrm{ha}{ }^{-1}$ recorded maximum number of branches at final harvest (13.61). 
Among the interaction effects between nitrogen and potassium on number of branches at final harvest, maximum number of branches (17.17) was recorded when crop applied with $120 \mathrm{~kg} \mathrm{~N}+120 \mathrm{~kg} \mathrm{~K} \mathrm{ha}^{-1}$ $\left(\mathrm{N}_{4} \mathrm{~K}_{4}\right)$, which was on par with $120 \mathrm{~kg} \mathrm{~N}+90$ $\mathrm{kg} \mathrm{K} \mathrm{ha}^{-1}\left(\mathrm{~N}_{4} \mathrm{~K}_{3}\right)$ with 15.60 branches at final harvest respectively.

\section{Number of leaves per vine}

The data on the effect of different levels of nitrogen, potassium and their interactions on number of leaves per vine has recorded at final harvest are rendered in table 2. At final harvest, maximum number of leaves (221.53) was recorded with application of $120 \mathrm{~kg} \mathrm{~N}$ ha ${ }^{1}\left(\mathrm{~N}_{4}\right)$, which was followed by $90 \mathrm{~kg} \mathrm{~N} \mathrm{ha}{ }^{-1}$ with 158.35 (at final harvest) number of leaves per vine. While the lowest number of leaves were observed when applied with 30 $\mathrm{kg} \mathrm{N} \mathrm{ha}^{-1}\left(\mathrm{~N}_{1}\right)$ at final harvest (105.11).

The maximum number of leaves was observed with application of $120 \mathrm{~kg} \mathrm{~K} \mathrm{ha}^{-1}$ $\left(\mathrm{K}_{4}\right)$ at final harvest (168.21). The application of $30 \mathrm{~kg} \mathrm{~K} \mathrm{ha}^{-1}\left(\mathrm{~K}_{1}\right)$ at final harvest (133.33) had recorded the minimum number of leaves per vine.

The combined application of $120 \mathrm{~kg} \mathrm{~N} \mathrm{ha}^{-1}+$ $120 \mathrm{~kg} \mathrm{~K} \mathrm{ha}^{-1}$ had recorded highest number of leaves (246.35) at final harvest which was on par with $120 \mathrm{~kg} \mathrm{~N}+90 \mathrm{~kg} \mathrm{~K} \mathrm{ha}^{-1}$ at final harvest (237.00). The least number of leaves per vine were found with $30 \mathrm{~kg} \mathrm{~N}+30 \mathrm{~kg} \mathrm{~K}$ $\mathrm{ha}^{-1}\left(\mathrm{~N}_{1} \mathrm{~K}_{1}\right)$ which was the lowest level tried in the experiment at all growth stages.

\section{Total leaf area per vine (' $\left.000 \mathrm{~cm}^{2}\right)$}

The data on the effect of different levels of nitrogen, potassium and their interactions on total leaf area per vine has recorded at final harvest are rendered in table 2. At final harvest, the maximum total leaf area per vine $\left(14.08 \mathrm{~cm}^{2}\right)$ was obtained when the crop applied with $120 \mathrm{~kg} \mathrm{~N} \mathrm{ha}^{-1}\left(\mathrm{~N}_{4}\right)$, which was significantly superior to all other treatments. It was followed by $90 \mathrm{~kg} \mathrm{~N}$ ha ${ }^{-1}\left(\mathrm{~N}_{3}\right)$ with total leaf area of $7.31 \mathrm{~cm}^{2}$. The minimum total leaf area of $3.18 \mathrm{~cm}^{2}$ was obtained with $30 \mathrm{~kg}$ $\mathrm{N} \mathrm{ha}^{-1}\left(\mathrm{~N}_{1}\right)$ at final harvest.

Among the different levels of potassium at final harvest, the highest total leaf area (9.24 $\mathrm{cm}^{2}$ ) was observed with the application of 120 $\mathrm{kg} \mathrm{K} \mathrm{ha}{ }^{-1}\left(\mathrm{~K}_{4}\right)$ which was followed by crop applied with $90 \mathrm{~kg} \mathrm{~K} \mathrm{ha}^{-1}$. The lowest total leaf area at final harvest $\left(5.67 \mathrm{~cm}^{2}\right)$ were recorded when applied with $30 \mathrm{~kg} \mathrm{~K} \mathrm{ha}^{-1}\left(\mathrm{~K}_{1}\right)$.

With respect to interactions, application of $120 \mathrm{~kg} \mathrm{~N}+120 \mathrm{~kg} \mathrm{~K} \mathrm{ha}^{-1}\left(\mathrm{~N}_{4} \mathrm{~K}_{4}\right)$ recorded maximum total leaf area at final harvest $\left(18.95 \mathrm{~cm}^{2}\right)$ which was followed by $120 \mathrm{~kg} \mathrm{~N}$ $+90 \mathrm{~kg} \mathrm{~K} \mathrm{ha}^{-1}$. The minimum total leaf area $\left(2.37 \mathrm{~cm}^{2}\right)$ was recorded when crop applied with $30 \mathrm{~kg} \mathrm{~N} \mathrm{ha}^{-1}+30 \mathrm{~kg} \mathrm{~K} \mathrm{ha}^{-1}\left(\mathrm{~N}_{1} \mathrm{~K}_{1}\right)$ at final harvest.

The plants fed with low levels of nitrogen and potassium were under developed and shorter in stature. These results are in confirmation with the findings of Bishnu et al., (2006) in potato and Imran et al., (2010) in colocasia.

\section{Yield parameters}

The data on the effects of different levels of nitrogen, potassium and their interactions on the number of root tubers per vine, root tuber length, root tuber girth, vine dry matter content, root tuber dry matter content, root tuber yield per vine, root tuber yield per plot and estimated root tuber yield per hectare are presented below.

\section{Number of tubers per vine}

The data on the effect of different levels of nitrogen, potassium and their interactions on 
number of tubers per vine were recorded at final harvest rendered in table 3.

The maximum number of root tubers per vine (4.10) was obtained when the crop applied with $120 \mathrm{~kg} N$ ha $^{-1}\left(\mathrm{~N}_{4}\right)$, which was significantly superior to all other treatments. It was followed by $90 \mathrm{~kg} \mathrm{~N}$ ha $^{-1}\left(\mathrm{~N}_{3}\right)$ with 2.68 root tubers per vine. The minimum number of root tubers per vine (1.74) was obtained with $30 \mathrm{~kg} \mathrm{~N} \mathrm{ha}^{-1}\left(\mathrm{~N}_{1}\right)$.

Among the different levels of potassium, the highest number of root tubers per vine (3.12) was observed with $120 \mathrm{~kg} \mathrm{~K} \mathrm{ha}^{-1}\left(\mathrm{~K}_{4}\right)$ which was on par with crop applied with $90 \mathrm{~kg} \mathrm{~K}$ ha ${ }^{1}$ having 2.76 root tubers per vine. The lowest number of root tubers (2.40) was recorded in plants applied with $30 \mathrm{~kg} \mathrm{~K} \mathrm{ha}^{-1}\left(\mathrm{~K}_{1}\right)$.

Application of $120 \mathrm{~kg} \mathrm{~N}+120 \mathrm{~kg} \mathrm{~K} \mathrm{ha}^{-1}$ $\left(\mathrm{N}_{4} \mathrm{~K}_{4}\right)$ recorded maximum number of root tubers per vine (5.00). The minimum number of root tubers per vine (1.40) was recorded in crop applied with $30 \mathrm{~kg} \mathrm{~N} \mathrm{ha}^{-1}+30 \mathrm{~kg} \mathrm{~K} \mathrm{ha}^{-1}$ $\left(\mathrm{N}_{1} \mathrm{~K}_{1}\right)$.

\section{Root tuber length (cm)}

The data on the effect of different levels of nitrogen, potassium and their interactions on root tuber length has recorded at final harvest are rendered in table 3 .

The maximum root tuber length $(15.47 \mathrm{~cm})$ was recorded with application of $120 \mathrm{~kg} \mathrm{~N}^{-}$ ${ }^{1}\left(\mathrm{~N}_{4}\right)$. The minimum root tuber length $(6.87$ $\mathrm{cm})$ was observed in crop applied with $30 \mathrm{~kg}$ $\mathrm{N} \mathrm{ha}{ }^{-1}\left(\mathrm{~N}_{1}\right)$.

Among the different levels of potassium, maximum root tuber length $(12.46 \mathrm{~cm})$ was recorded with $120 \mathrm{~kg} \mathrm{~K} \mathrm{ha}^{-1}\left(\mathrm{~K}_{4}\right)$ application which was on par with $90 \mathrm{~kg} \mathrm{~K} \mathrm{ha}^{-1}\left(\mathrm{~K}_{3}\right)$ with root tuber length of $11.65 \mathrm{~cm}$, whereas minimum root tuber length $(9.79 \mathrm{~cm})$ was recorded in crop applied with $30 \mathrm{~kg} \mathrm{~K}^{-1}$ $\left(\mathrm{K}_{1}\right)$.

Regarding interactions, maximum root tuber length $(17.69 \mathrm{~cm})$ was recorded when the crop applied with $120 \mathrm{~kg} \mathrm{~N}+120 \mathrm{~kg} \mathrm{~K} \mathrm{ha}^{-1}$ $\left(\mathrm{N}_{4} \mathrm{~K}_{4}\right)$, which might be due to higher amount of nutrients available in this treatment compared to other treatments.

\section{Root tuber girth (cm)}

The data on the effect of different levels of nitrogen, potassium and their interactions on root tuber girth has recorded at final harvest are rendered in table 4 .

Among the different levels of nitrogen, the maximum root tuber girth $(17.22 \mathrm{~cm})$ was observed with $120 \mathrm{~kg} \mathrm{~N}^{-1}\left(\mathrm{~N}_{4}\right)$ which was significantly superior to all other treatments followed by $90 \mathrm{~kg} \mathrm{~N}^{-1}\left(\mathrm{~N}_{3}\right)$ with $15.57 \mathrm{~cm}$. The minimum tuber girth $(12.54 \mathrm{~cm})$ was observed with $30 \mathrm{~kg} \mathrm{~N} \mathrm{ha}^{-1}\left(\mathrm{~N}_{1}\right)$.

With respect to different levels of potassium the maximum root tuber girth $(16.11 \mathrm{~cm})$ was recorded with application of $120 \mathrm{~kg} \mathrm{~K} \mathrm{ha}{ }^{-1}$ $\left(\mathrm{K}_{4}\right)$ which was on par with $90 \mathrm{~kg} \mathrm{~K} \mathrm{ha}{ }^{-1}$ with $15.42 \mathrm{~cm}$. The minimum root tuber girth $(13.68 \mathrm{~cm})$ was observed with $30 \mathrm{~kg} \mathrm{~K} \mathrm{ha}^{-1}$ $\left(\mathrm{K}_{1}\right)$.

The highest root tuber girth $(20.02 \mathrm{~cm})$ was recorded when the crop applied with $120 \mathrm{~kg}$ $\mathrm{N}+120 \mathrm{~kg} \mathrm{~K}^{-1}$. And minimum root tuber girth $(10.78 \mathrm{~cm})$ was observed with $30 \mathrm{~kg} \mathrm{~N}+$ $30 \mathrm{~kg} \mathrm{~K} \mathrm{ha}{ }^{-1}\left(\mathrm{~N}_{1} \mathrm{~K}_{1}\right)$ which might be due to higher amount of nutrients available in this treatment compared to other treatments.

The findings are in conformity with Bishnu et al., (2006) in potato, Chattopadhyay et al., (2006) and Nedunchezhiyan et al., (2010) in greater yam. 


\section{Vine dry matter content (\%)}

The data on the effect of different levels of nitrogen, potassium and their interactions on vine dry matter content has recorded at final harvest are rendered in table 4.The data clearly showed that the vine tuber dry matter content significantly increased with increasing levels of nitrogen and potassium and their interactions. The maximum vine dry matter content $(31.61 \%)$ was obtained in the crop applied with $120 \mathrm{~kg} \mathrm{~N} \mathrm{ha}^{-1}\left(\mathrm{~N}_{4}\right)$, which was significantly superior to all other treatments. It was followed by $90 \mathrm{~kg} \mathrm{~N} \mathrm{ha}{ }^{-1}$ $\left(\mathrm{N}_{3}\right)$ with $29.67 \%$ vine dry matter content. The minimum vine dry matter content $(22.79 \%)$ was obtained with $30 \mathrm{~kg} \mathrm{~N} \mathrm{ha}{ }^{-1}$ $\left(\mathrm{N}_{1}\right)$.

Among different levels of potassium, the maximum vine dry matter content $(28.78 \%)$ was recorded with $120 \mathrm{~kg} \mathrm{~K} \mathrm{ha}^{-1}$, which was on par with $90 \mathrm{~kg} \mathrm{~K} \mathrm{ha}^{-1}\left(\mathrm{~K}_{3}\right)$ with $27.97 \%$. The lowest vine dry matter content $(26.67 \%)$ was observed when the crop applied with 30 $\mathrm{kg} \mathrm{ha}^{-1}\left(\mathrm{~K}_{1}\right)$.

The application of $120 \mathrm{~kg} \mathrm{~N}+120 \mathrm{~kg} \mathrm{~K} \mathrm{ha}^{-1}$ $\left(\mathrm{N}_{4} \mathrm{~K}_{4}\right)$ resulted in maximum vine dry matter content $(32.39 \%)$ and the least vine dry matter content $(21.90 \%)$ was recorded with application of $30 \mathrm{~kg} \mathrm{~N}+30 \mathrm{~kg} \mathrm{~K} \mathrm{ha}^{-1}\left(\mathrm{~N}_{1} \mathrm{~K}_{1}\right)$.

\section{Root tuber dry matter content (\%)}

The data on the effects of different levels of nitrogen, potassium and their interactions on the root tuber dry matter content are presented in table 5 .

The root tuber dry matter content increased linearly with increase in the levels of nitrogen and potassium. The maximum tuber dry matter content $(30.07 \%)$ was obtained with $120 \mathrm{~kg} \mathrm{~N} \mathrm{ha}^{-1}\left(\mathrm{~N}_{4}\right)$, which was significantly superior to all other treatments. It was followed by $90 \mathrm{~kg} \mathrm{~N} \mathrm{ha}^{-1}\left(\mathrm{~N}_{3}\right)$ with $27.27 \%$ root tubers dry matter content. The minimum root tuber dry matter content $(25.00 \%)$ was obtained with $30 \mathrm{~kg} \mathrm{~N} \mathrm{ha}^{-1}\left(\mathrm{~N}_{1}\right)$.

In respect of different potassium levels, the maximum root tuber dry matter content (28.03\%) was recorded with $120 \mathrm{~kg} \mathrm{~K} \mathrm{ha}^{-1}$ application, which was on par with $90 \mathrm{~kg} \mathrm{~K}$ $\mathrm{ha}^{-1}\left(\mathrm{~K}_{3}\right)$ with $27.45 \%$. The minimum tuber dry matter content $(26.42 \%)$ was observed when crop applied with $30 \mathrm{~kg} \mathrm{~K}^{-1}\left(\mathrm{~K}_{1}\right)$.

The application of $120 \mathrm{~kg} \mathrm{~N}+120 \mathrm{~kg} \mathrm{~K}$ ha $^{-1}$ $\left(\mathrm{N}_{4} \mathrm{~K}_{4}\right)$ resulted in maximum root tuber dry matter content $(32.17 \%)$, followed by $120 \mathrm{~kg}$ $\mathrm{N}+90 \mathrm{~kg} \mathrm{~K} \mathrm{ha}^{-1}\left(\mathrm{~N}_{3} \mathrm{~K}_{3}\right)$ with $30.44 \%$. The lowest root tuber dry matter content $(24.25 \%)$ was recorded with application of 30 $\mathrm{kg} \mathrm{N}+30 \mathrm{~kg} \mathrm{~K} \mathrm{ha}^{-1}\left(\mathrm{~N}_{1} \mathrm{~K}_{1}\right)$.

\section{Root tuber yield per vine (g)}

The data on the effect of different levels of nitrogen, potassium and their interactions on root tuber yield per vine has recorded at final harvest are rendered in table 5.

The root tuber yield per vine was found to be highest $(381.29 \mathrm{~g})$ in crop applied with $120 \mathrm{~kg}$ $\mathrm{N} \mathrm{ha}^{-1}\left(\mathrm{~N}_{4}\right)$, which was significantly superior to all other levels of nitrogen. It was followed by $90 \mathrm{~kg} \mathrm{~N} \mathrm{ha}^{-1}\left(\mathrm{~N}_{3}\right)$ with root tuber yield of $294.57 \mathrm{~g}$. The lowest root tuber yield (134.38 g) was observed with application of $30 \mathrm{~kg} \mathrm{~N}$ $\mathrm{ha}^{-1}\left(\mathrm{~N}_{1}\right)$.

Among the four different levels of potassium, the maximum root tuber yield per vine $(292.79 \mathrm{~g})$ was recorded in crop applied with $120 \mathrm{~kg} \mathrm{~K} \mathrm{ha}^{-1}\left(\mathrm{~K}_{4}\right)$ which was significantly superior to all other levels of potassium. The minimum root tuber yield per vine $(230.17 \mathrm{~g})$ was observed with $30 \mathrm{~kg} \mathrm{~K} \mathrm{ha}{ }^{-1}\left(\mathrm{~K}_{1}\right)$ application. 
The application of $120 \mathrm{~kg} \mathrm{~N}+120 \mathrm{~kg} \mathrm{~K} \mathrm{ha}^{-1}$ $\left(\mathrm{N}_{4} \mathrm{~K}_{4}\right)$ resulted with the significantly highest yield $(445.98 \mathrm{~g}$ ) followed by $120 \mathrm{~kg} \mathrm{~N}+90$ kg K ha ${ }^{-1}\left(\mathrm{~N}_{3} \mathrm{~K}_{3}\right)$ with 389.10 g. Significantly lowest yield (122.22 g) was recorded with application of $30 \mathrm{~kg} \mathrm{~N}+60 \mathrm{~kg} \mathrm{~K} \mathrm{ha}^{-1}\left(\mathrm{~N}_{1} \mathrm{~K}_{2}\right)$.

\section{Root tuber yield per plot (kg)}

The data on the effect of different levels of nitrogen, potassium and their interactions on root tuber yield per plot has recorded at final harvest are rendered in table 6 . The data on the effect of different levels of nitrogen, potassium and their interactions on root tuber yield per plot has recorded at final harvest are rendered in table 6.The data clearly showed that the root tuber yield per plot significantly increased with increasing levels of nitrogen and potassium. The maximum root tuber yield per plot $(19.19 \mathrm{~kg})$ was obtained in the crop applied with $120 \mathrm{~kg} \mathrm{~N}^{-1}\left(\mathrm{~N}_{4}\right)$, which was significantly superior to all other treatments. It was followed by $90 \mathrm{~kg} \mathrm{~N} \mathrm{ha}{ }^{-1}\left(\mathrm{~N}_{3}\right)$ with $15.86 \mathrm{~kg}$ root tubers yield per plot. The minimum root tuber yield per plot $(7.61 \mathrm{~kg})$ was obtained with $30 \mathrm{~kg} \mathrm{~N} \mathrm{ha}^{-1}\left(\mathrm{~N}_{1}\right)$.

Among different potassium levels, the maximum root tuber yield per plot $(15.13 \mathrm{~kg})$ was recorded with $120 \mathrm{~kg} \mathrm{~K}^{-1}$ which was followed by $90 \mathrm{~kg} \mathrm{~K} \mathrm{ha}^{-1}(14.11 \mathrm{~kg})$. The minimum tuber yield per plot $(12.28 \mathrm{~kg})$ was observed in crop applied with $30 \mathrm{~kg} \mathrm{ha}^{-1}\left(\mathrm{~K}_{1}\right)$. The application of $120 \mathrm{~kg} \mathrm{~N}+120 \mathrm{~kg} \mathrm{~K} \mathrm{ha}^{-1}$ $\left(\mathrm{N}_{4} \mathrm{~K}_{4}\right)$ resulted in maximum root tuber yield per plot $(20.92 \mathrm{~kg})$ which was followed by $120 \mathrm{~kg} \mathrm{~N}+90 \mathrm{~kg} \mathrm{~K} \mathrm{ha}^{-1}\left(\mathrm{~N}_{3} \mathrm{~K}_{3}\right)$ with 19.60 $\mathrm{kg}$. The lowest root tuber yield per plot $(5.17$ $\mathrm{kg}$ ) was recorded with application of $30 \mathrm{~kg} \mathrm{~N}$ $+30 \mathrm{~kg} \mathrm{~K} \mathrm{ha}^{-1}\left(\mathrm{~N}_{1} \mathrm{~K}_{1}\right)$.

\section{Estimated root yield per hectare $(t)$}

The data on the effect of different levels of nitrogen, potassium and their interactions on estimated root tuber yield per hectare has recorded at final harvest are rendered in table 6.The data had clearly showed that the root tuber yield $\left(\mathrm{t} \mathrm{ha}^{-1}\right)$ increased gradually with increase in the levels of nitrogen and potassium. Significantly highest root tuber yield $\left(25.58 \mathrm{t} \mathrm{ha}^{-1}\right)$ was observed with application of $120 \mathrm{~kg} \mathrm{~N} \mathrm{ha}^{-1}\left(\mathrm{~N}_{4}\right)$ followed by $90 \mathrm{~kg} \mathrm{~N}$ ha $^{-1}\left(\mathrm{~N}_{3}\right)$ with $21.15 \mathrm{t} \mathrm{ha}^{-1}$. The lowest root tuber yield $\left(10.14 \mathrm{t} \mathrm{ha}^{-1}\right)$ was recorded in the crop applied with $30 \mathrm{~kg} \mathrm{~N} \mathrm{ha}^{-1}$ $\left(\mathrm{N}_{1}\right)$. The maximum root tuber yield $(20.18 \mathrm{t}$ $\mathrm{ha}^{-1}$ ) was recorded with $120 \mathrm{~kg} \mathrm{~K} \mathrm{ha}^{-1}$ which was significantly superior to other levels of potassium and followed by $90 \mathrm{~kg} \mathrm{~K} \mathrm{ha}^{-1}\left(\mathrm{~K}_{3}\right)$ with $18.82 \mathrm{t} \mathrm{ha}^{-1}$. The minimum root tuber yield $\left(16.38 \mathrm{t} \mathrm{ha}^{-1}\right)$ was observed in crop applied with $30 \mathrm{~kg} \mathrm{ha}^{-1}\left(\mathrm{~K}_{1}\right)$.

Among interactions, the maximum root tuber yield (27.89 $\left.\mathrm{t} \mathrm{ha}^{-1}\right)$ was recorded with an application of $120 \mathrm{~kg} \mathrm{~N}+120 \mathrm{~kg} \mathrm{~K} \mathrm{ha}^{-1}$ $\left(\mathrm{N}_{4} \mathrm{~K}_{4}\right)$, which was followed by $120 \mathrm{~kg} \mathrm{~N}+$ $90 \mathrm{~kg} \mathrm{~K} \mathrm{ha}^{-1}\left(\mathrm{~N}_{4} \mathrm{~K}_{3}\right)$ with a yield of $26.13 \mathrm{t} \mathrm{ha}^{-}$ ${ }^{1}$. The lowest root tuber yield $\left(6.89 \mathrm{t} \mathrm{ha}^{-1}\right)$ was observed in crop applied with $30 \mathrm{~kg} \mathrm{~N}+30$ $\mathrm{kg} \mathrm{K} \mathrm{ha}{ }^{-1}\left(\mathrm{~N}_{1} \mathrm{~K}_{1}\right)$.

The significant increase in the tuber yield per plot with the of application of potassium may be due to positive response of tuber yield and yielding components and could be attributed to high starch synthesis and translocation activities stimulated by K application. Similar result was obtained with Uwah et al., (2013) with added $\mathrm{K}$ thus suggesting that the $\mathrm{K}$ application increases yield through the formation of large size tubers in sweet potato.

\section{Quality parameters}

\section{$\beta$-carotene content}

The data on the effect of different levels of nitrogen, potassium and their interactions on beta carotene content has recorded at final 
harvest are rendered in table 7.The data regarding the influence of different levels of nitrogen, potassium and their interactions on the $\beta$-carotene in tubers are presented. The data had clearly showed that the $\beta$-carotene increased gradually with increase in the levels of nitrogen. Significant differences were observed in different levels of nitrogen and potassium and their interactions.

The highest $\beta$-carotene (12.56 mg/100g f.w.) was recorded in the crop applied with $120 \mathrm{~kg}$ $\mathrm{N} \mathrm{ha}^{-1}\left(\mathrm{~N}_{4}\right)$ which was followed by $90 \mathrm{~kg} \mathrm{~N}$ ha $^{-1}\left(\mathrm{~N}_{3}\right)$ with $11.96 \mathrm{mg} / 100 \mathrm{~g}$ f.w. The lowest $\beta$-carotene $(9.86 \mathrm{mg} / 100 \mathrm{~g}$ f.w.) was observed with the application of $30 \mathrm{~kg} \mathrm{~N} \mathrm{ha}{ }^{-1}\left(\mathrm{~N}_{1}\right)$. Among different potassium levels, the maximum $\beta$-carotene (11.86 mg/100g f.w.) was observed in crop applied with $120 \mathrm{~kg} \mathrm{~K}$ $\mathrm{ha}^{-1}\left(\mathrm{~K}_{4}\right)$ and the minimum $\beta$-carotene $(10.94$ $\mathrm{mg} / 100 \mathrm{~g}$ f.w.) was recorded with $30 \mathrm{~kg} \mathrm{~K}$ ha ${ }^{1}$ application $\left(\mathrm{K}_{1}\right)$. Regarding interactions, the highest $\beta$-carotene (12.92 mg/100g f.w.) was observed in crop applied with $120 \mathrm{~kg} \mathrm{~N}+120$ $\mathrm{kg} \mathrm{K} \mathrm{ha}{ }^{-1}\left(\mathrm{~N}_{4} \mathrm{~K}_{4}\right)$. Whereas, the lowest $\beta$ carotene $(9.45 \mathrm{mg} / 100 \mathrm{~g}$ f.w.) was recorded with the application of $30 \mathrm{~kg} \mathrm{~N}+30 \mathrm{~kg} \mathrm{~K} \mathrm{ha}^{-1}$ $\left(\mathrm{N}_{1} \mathrm{~K}_{1}\right)$.

\section{Starch content (\%)}

The data regarding the influence of different levels of nitrogen, potassium and their interactions on the starch in tubers are presented in table 7 .

The different levels of nitrogen and potassium and their interaction had showed significant influence on starch content. The data had clearly depicted that the starch content in root tubers decreased gradually with increase in the levels of nitrogen. Significantly highest starch content $(14.98 \%)$ was observed with the application of $30 \mathrm{~kg} \mathrm{~N} \mathrm{ha}^{-1}\left(\mathrm{~N}_{1}\right)$ followed by $60 \mathrm{~kg} \mathrm{~N} \mathrm{ha}^{-1}\left(\mathrm{~N}_{2}\right)$ with $12.90 \%$. The lowest starch content $(11.63 \%)$ was observed with
$120 \mathrm{~kg} \mathrm{~N} \mathrm{ha}^{-1}\left(\mathrm{~N}_{4}\right)$. Significant increase in the percentage of starch content was observed at $120 \mathrm{~kg} \mathrm{~K} \mathrm{ha}^{-1}$ over 30,60 and $90 \mathrm{~kg} \mathrm{~K} \mathrm{ha}^{-1}$. The starch content $(14.69 \%)$ was found to be maximum with crop applied with $120 \mathrm{~kg} \mathrm{~K}$ $\mathrm{ha}^{-1}$ followed by $90 \mathrm{~kg} \mathrm{~K} \mathrm{ha}^{-1}$ with $13.95 \%$. The lowest starch content (11.11\%) was found with $30 \mathrm{~kg} \mathrm{~K} \mathrm{ha}^{-1}$. The maximum starch content $(16.95 \%)$ was recorded with an application of $30 \mathrm{~kg} \mathrm{~N}+120 \mathrm{~kg} \mathrm{~K} \mathrm{ha}^{-1}\left(\mathrm{~N}_{1} \mathrm{~K}_{4}\right)$ followed by $60 \mathrm{~kg} \mathrm{~N} \mathrm{ha}^{-1}+120 \mathrm{~kg} \mathrm{~K} \mathrm{ha}^{-1}$ $\left(\mathrm{N}_{2} \mathrm{~K}_{4}\right)$ with $14.64 \%$, whereas minimum starch content $(10.28 \%)$ was recorded with crop applied with $120 \mathrm{~kg} \mathrm{~N}+30 \mathrm{~kg} \mathrm{~K} \mathrm{ha}^{-1}$ $\left(\mathrm{N}_{4} \mathrm{~K}_{1}\right)$.

Application of nitrogen decreased the starch content of tubers markedly. This may be due to nitrogen which promoted the growth of additional tissues at the cost of photosynthesis, thus leaving a little balance of carbohydrate for accumulation in the form of starch, whereas application of potassium increased the starch content. This increase can be due to potassium which helped in the formation and transfer of starch and sugar from leaves to the tubers. These results are in agreement with the findings of Hukheri (1968), Narsa Reddy and Suryanarayana (1968) in potato, Rajendran et al., (1971) in sweet potato and Gupta and Saxena (1976) in potato.

\section{Reducing sugars (\%)}

The data regarding the influence of different levels of nitrogen, potassium and their interactions on the reducing sugars in root tubers are presented in table 8 .

The data had clearly showed that, significant differences were not observed in different levels of potassium and the interaction between nitrogen and potassium. The highest reducing sugars $(3.88 \%)$ were recorded in the crop applied with $90 \mathrm{~kg} \mathrm{~N} \mathrm{ha}{ }^{-1}\left(\mathrm{~N}_{3}\right)$ which 
was on par with $120 \mathrm{~kg} \mathrm{~N} \mathrm{ha}^{-1}\left(\mathrm{~N}_{4}\right)$ with 3.87 $\%$ of reducing sugars and the lowest reducing sugars $(3.71 \%)$ were observed with the application of $30 \mathrm{~kg} \mathrm{~N}$ ha $^{-1}\left(\mathrm{~N}_{1}\right)$. Among different potassium levels, the maximum reducing sugars $(3.81 \%)$ were observed in crop applied with $120 \mathrm{~kg} \mathrm{~K} \mathrm{ha}^{-1}\left(\mathrm{~K}_{4}\right)$ and the minimum reducing sugars $(3.75 \%)$ were recorded with $30 \mathrm{~kg} \mathrm{~K} \mathrm{ha}^{-1}$ application $\left(\mathrm{K}_{1}\right)$. In respect of interactions, the highest reducing sugars $(3.96 \%)$ were observed in crop applied with $120 \mathrm{~kg} \mathrm{~N}+120 \mathrm{~kg} \mathrm{~K} \mathrm{ha}{ }^{-1}\left(\mathrm{~N}_{4} \mathrm{~K}_{4}\right)$. Whereas, the lowest reducing sugars $(3.62 \%)$ were recorded with the application of $30 \mathrm{~kg} \mathrm{~N}$ $+90 \mathrm{~kg} \mathrm{Kha}^{-1}\left(\mathrm{~N}_{1} \mathrm{~K}_{3}\right)$.

\section{Non-reducing sugars (\%)}

The data regarding the influence of different levels of nitrogen, potassium and their interactions on the non-reducing sugars in root tubers of sweet potato are presented in table 8. Significant differences were observed in non-reducing sugars among different levels of nitrogen and potassium. However, no significant differences were observed among the treatment combinations between nitrogen and potassium.

The highest non-reducing sugars $(0.79 \%)$ were observed with the application of $120 \mathrm{~kg}$ $\mathrm{N} \mathrm{ha}^{-1}\left(\mathrm{~N}_{4}\right)$ which was on par with $90 \mathrm{~kg} \mathrm{~N}$ $\mathrm{ha}^{-1}(0.75 \%)$. The least non-reducing sugars $(0.62 \%)$ were recorded in the crop applied with $30 \mathrm{~kg} \mathrm{~N}$ ha $^{-1}\left(\mathrm{~N}_{1}\right)$. The maximum nonreducing sugars $(0.83 \%)$ were recorded with $120 \mathrm{~kg} \mathrm{~K} \mathrm{ha}^{-1}$ application $\left(\mathrm{K}_{4}\right)$ which was on par with $90 \mathrm{~kg} \mathrm{~K} \mathrm{ha}^{-1}(0.76 \%)$. The minimum non-reducing sugars $(0.63 \%)$ were observed in crop applied with $60 \mathrm{~kg} \mathrm{~K} \mathrm{ha}{ }^{-1}\left(\mathrm{~K}_{2}\right)$. With respect to interactions, the highest nonreducing sugars $(0.90 \%)$ were recorded with the application of $120 \mathrm{~kg} \mathrm{~N}+120 \mathrm{~kg} \mathrm{~K} \mathrm{ha}^{-1}$ $\left(\mathrm{N}_{4} \mathrm{~K}_{4}\right)$, whereas the least non-reducing sugars $(0.48 \%)$ were observed in crop applied with $30 \mathrm{~kg} \mathrm{~N}+60 \mathrm{~kg} \mathrm{~K} \mathrm{ha}^{-1}\left(\mathrm{~N}_{1} \mathrm{~K}_{2}\right)$.

\section{Total sugars $(\%)$}

The per cent total sugars in root tubers of sweet potato as influenced by different levels of nitrogen, potassium and their interactions was calculated and presented in table 9. No significant difference was observed among the interaction effects of nitrogen and potassium in total sugar content.

The maximum total sugar content (4.67\%) was observed with the application of $120 \mathrm{~kg}$ $\mathrm{N}$ ha $^{-1}\left(\mathrm{~N}_{4}\right)$ followed by $90 \mathrm{~kg} \mathrm{~N} \mathrm{ha}{ }^{-1}\left(\mathrm{~N}_{3}\right)$ with $4.63 \%$ and the least total sugar content $(4.33 \%)$ was observed with $30 \mathrm{~kg} \mathrm{~N} \mathrm{ha}^{-1}\left(\mathrm{~N}_{1}\right)$. The application of $120 \mathrm{~kg} \mathrm{~K} \mathrm{ha}{ }^{-1}$ recorded maximum total sugar content $(4.64 \%)$ which was on par with $90 \mathrm{~kg} \mathrm{~K} \mathrm{ha}^{-1}$ with $4.54 \%$.

The minimum total sugar content $(4.42 \%)$ was observed in crop applied with $30 \mathrm{~kg} \mathrm{~K}$ ha ${ }^{1}\left(\mathrm{~K}_{1}\right)$. The crop applied with $120 \mathrm{~kg} \mathrm{~N}+120$ $\mathrm{K} \mathrm{kg} \mathrm{ha}^{-1}\left(\mathrm{~N}_{4} \mathrm{~K}_{4}\right)$ resulted in maximum total sugar content $(4.86 \%)$. The least total sugar content $(4.22 \%)$ was recorded with application of $30 \mathrm{~kg} \mathrm{~N}+30 \mathrm{~kg} \mathrm{~K} \mathrm{ha}^{-1}\left(\mathrm{~N}_{1} \mathrm{~K}_{1}\right)$.

This might be due to nitrogen significantly increasing the sucrose contents, recoverable sugar yield adding to the highest level of nitrogen and association existing between uptake and accumulation of nutrient in tuber and also between their combined role in enhancing the synthesis of sucrose content and accumulation in tubers.

Similar results were reported by Patil et al., (1990) in sweet potato. And the role of potassium in plant metabolic activity can be explained on the basis of the positive effect of translocation of assimilates, which are necessary for essential plant processes such as energy utilization and synthesis of sugars in tubers. Similar results were recorded by Bansal and Trehan (2011) in potato. 
The increased growth obtained at higher levels of fertilizers on different days after planting revealed that nitrogen had an encouraging effect on growth as it forms an important constituent of chlorophyll, proteins and amino acids which might had resulted in better photosynthesis. The role of potassium in photosynthesis is complex. The activation of enzyme by $\mathrm{K}$ and its involvement in ATP production is probably more important in regulating the rate of photosynthesis.

Significant increase in tuber yield with increase in nitrogen fertilizer might be due to higher level of $\mathrm{N}$ which increased the vegetative growth and development of the tuber crops and also increased tuberization. Similar results were obtained by Padmanabhan et al., (1975) in sweet potato and Leilah et al., (2005) in sugar beet.

Table.1 Effect of nitrogen and potassium on vine length $(\mathrm{cm})$ and number of branches per vine in sweet potato (Ipomoea batatasLam.)

\begin{tabular}{|c|c|c|c|c|c|c|c|c|c|c|}
\hline & \multicolumn{4}{|c|}{ Vine length (cm) } & \multicolumn{5}{c|}{ Number of branches per vine } \\
\hline & $\mathbf{K}_{\mathbf{1}}$ & $\mathbf{K}_{\mathbf{2}}$ & $\mathbf{K}_{\mathbf{3}}$ & $\mathbf{K}_{\mathbf{4}}$ & $\mathbf{M e a n}$ & $\mathbf{K}_{\mathbf{1}}$ & $\mathbf{K}_{\mathbf{2}}$ & $\mathbf{K}_{\mathbf{3}}$ & $\mathbf{K}_{\mathbf{4}}$ & Mean \\
\hline $\mathbf{N}_{\mathbf{1}}$ & 127.67 & 131.33 & 135.53 & 137.67 & $\mathbf{1 3 3 . 0 5}$ & 6.33 & 7.47 & 6.73 & 11.00 & $\mathbf{7 . 8 8}$ \\
\hline $\mathbf{N}_{\mathbf{2}}$ & 141.27 & 143.87 & 147.50 & 155.87 & $\mathbf{1 4 7 . 1 3}$ & 10.67 & 11.00 & 11.87 & 12.07 & $\mathbf{1 1 . 4 0}$ \\
\hline $\mathbf{N}_{\mathbf{3}}$ & 160.53 & 164.17 & 172.40 & 176.10 & $\mathbf{1 6 8 . 3 0}$ & 12.53 & 13.07 & 11.80 & 14.20 & $\mathbf{1 2 . 9 0}$ \\
\hline $\mathbf{N}_{\mathbf{4}}$ & 179.63 & 183.67 & 192.30 & 216.73 & $\mathbf{1 9 3 . 0 8}$ & 14.07 & 12.89 & 15.60 & 17.17 & $\mathbf{1 4 . 9 3}$ \\
\hline $\mathbf{M e a n}$ & $\mathbf{1 5 2 . 2 8}$ & $\mathbf{1 5 5 . 7 6}$ & $\mathbf{1 6 1 . 9 3}$ & $\mathbf{1 7 1 . 5 9}$ & & $\mathbf{1 0 . 9 0}$ & $\mathbf{1 1 . 1 1}$ & $\mathbf{1 1 . 5 0}$ & $\mathbf{1 3 . 6 1}$ \\
\hline & & $\mathbf{N}$ & $\mathbf{K}$ & $\mathbf{N} \times \mathbf{K}$ & $\mathbf{N}$ & $\mathbf{K}$ & $\mathbf{N} \times \mathbf{K}$ \\
\hline $\mathbf{S E m}$ & 2.515 & 2.515 & 5.030 & 0.351 & 0.351 & 0.702 \\
\hline C.D. at 5\% & 7.264 & 7.264 & 14.529 & 1.014 & 1.014 & 2.027 \\
\hline
\end{tabular}

Table.2 Effect of nitrogen and potassium on Number of leaves per vine and Total leaf area per vine ('000 $\mathrm{cm}^{2}$ ) in sweet potato (Ipomoea batatasLam.)

\begin{tabular}{|c|c|c|c|c|c|c|c|c|c|c|}
\hline & \multicolumn{5}{|c|}{ Number of leaves per vine } & \multicolumn{5}{|c|}{ Total leaf area per vine $\left({ }^{\circ} 000 \mathrm{~cm}^{2}\right)$} \\
\hline & $\mathbf{K}_{1}$ & $\mathbf{K}_{2}$ & $\mathbf{K}_{\mathbf{3}}$ & $\mathbf{K}_{4}$ & Mean & $\mathbf{K}_{1}$ & $\mathbf{K}_{2}$ & $\mathbf{K}_{\mathbf{3}}$ & $\mathbf{K}_{4}$ & Mean \\
\hline $\mathrm{N}_{1}$ & 93.83 & 101.10 & 103.50 & 122.00 & 105.11 & 2.37 & 2.81 & 3.31 & 4.22 & 3.18 \\
\hline $\mathbf{N}_{2}$ & 122.67 & 123.33 & 130.33 & 135.07 & 127.85 & 4.40 & 4.59 & 5.09 & 5.51 & 4.90 \\
\hline $\mathbf{N}_{3}$ & 145.27 & 159.20 & 159.53 & 169.40 & 158.35 & 6.38 & 7.23 & 7.34 & 8.28 & 7.31 \\
\hline $\mathbf{N}_{4}$ & 171.53 & 231.20 & 237.00 & 246.37 & 221.53 & 9.52 & 13.14 & 14.69 & 18.95 & 14.08 \\
\hline Mean & 133.33 & 153.71 & 157.59 & \multicolumn{2}{|l|}{168.21} & 5.67 & 6.94 & 7.61 & \multicolumn{2}{|c|}{9.24} \\
\hline & \multicolumn{2}{|r|}{$\mathbf{N}$} & \multicolumn{2}{|l|}{$\mathbf{K}$} & $\mathbf{N} \times \mathbf{K}$ & \multicolumn{2}{|c|}{$\mathbf{N}$} & $\mathbf{K}$ & \multicolumn{2}{|c|}{$\mathbf{N} \times \mathbf{K}$} \\
\hline \multicolumn{2}{|c|}{ SEm \pm} & 2.260 & \multicolumn{2}{|l|}{2.260} & \multirow{2}{*}{13.053} & \multicolumn{2}{|c|}{0.169} & 0.169 & \multicolumn{2}{|c|}{0.339} \\
\hline \multicolumn{2}{|c|}{ C.D. at $5 \%$} & 6.526 & \multicolumn{2}{|l|}{6.526} & & \multicolumn{2}{|c|}{0.489} & 0.489 & \multicolumn{2}{|c|}{0.978} \\
\hline
\end{tabular}


Table.3 Effect of nitrogen and potassium on number of root tubers per vine and root tuber length $(\mathrm{cm})$ in sweet potato (Ipomoea batatas Lam.)

\begin{tabular}{|c|c|c|c|c|c|c|c|c|c|c|}
\hline & \multicolumn{9}{|c|}{ Number of root tubers per vine } & \multicolumn{4}{c|}{ Root tuber length (cm) } \\
\hline & $\mathbf{K}_{\mathbf{1}}$ & $\mathbf{K}_{\mathbf{2}}$ & $\mathbf{K}_{\mathbf{3}}$ & $\mathbf{K}_{\mathbf{4}}$ & $\mathbf{M e a n}$ & $\mathbf{K}_{\mathbf{1}}$ & $\mathbf{K}_{\mathbf{2}}$ & $\mathbf{K}_{\mathbf{3}}$ & $\mathbf{K}_{\mathbf{4}}$ & Mean \\
\hline $\mathbf{N}_{\mathbf{1}}$ & 1.40 & 1.67 & 1.83 & 2.07 & $\mathbf{1 . 7 4}$ & 5.62 & 6.75 & 6.95 & 8.14 & $\mathbf{6 . 8 7}$ \\
\hline $\mathbf{N}_{\mathbf{2}}$ & 2.13 & 2.20 & 2.37 & 2.40 & $\mathbf{2 . 2 8}$ & 9.75 & 9.82 & 12.31 & 11.51 & $\mathbf{1 0 . 8 5}$ \\
\hline $\mathbf{N}_{\mathbf{3}}$ & 2.53 & 2.57 & 2.63 & 3.00 & $\mathbf{2 . 6 8}$ & 10.89 & 11.11 & 11.47 & 12.49 & $\mathbf{1 1 . 4 9}$ \\
\hline $\mathbf{N}_{\mathbf{4}}$ & 3.53 & 3.67 & 4.20 & 5.00 & $\mathbf{4 . 1 0}$ & 12.89 & 15.47 & 15.84 & 17.69 & $\mathbf{1 5 . 4 7}$ \\
\hline Mean & $\mathbf{2 . 4 0}$ & $\mathbf{2 . 5 3}$ & $\mathbf{2 . 7 6}$ & $\mathbf{3 . 1 2}$ & & $\mathbf{9 . 7 9}$ & $\mathbf{1 0 . 7 9}$ & $\mathbf{1 1 . 6 5}$ & $\mathbf{1 2 . 4 6}$ & \\
\hline & & $\mathbf{N}$ & $\mathbf{K}$ & $\mathbf{N} \times \mathbf{K}$ & $\mathbf{N}$ & $\mathbf{K}$ & $\mathbf{N} \times \mathbf{K}$ \\
\hline $\mathbf{S E m} \pm$ & 0.153 & 0.153 & 0.306 & 0.328 & 0.328 & 0.656 \\
\hline C.D. at 5\% & 0.442 & 0.442 & & NS & 0.947 & 0.947 & NS \\
\hline
\end{tabular}

Table.4 Effect of nitrogen and potassium on root tuber girth $(\mathrm{cm})$ and vine dry matter content $(\%)$ in sweet potato (Ipomoea batatas Lam.)

\begin{tabular}{|c|c|c|c|c|c|c|c|c|c|c|}
\hline & \multicolumn{4}{|c|}{ Root tuber girth $(\mathbf{c m})$} & \multicolumn{4}{c|}{ Vine dry matter content (\%) } \\
\hline & $\mathbf{K}_{\mathbf{1}}$ & $\mathbf{K}_{\mathbf{2}}$ & $\mathbf{K}_{\mathbf{3}}$ & $\mathbf{K}_{\mathbf{4}}$ & $\mathbf{M e a n}$ & $\mathbf{K}_{\mathbf{1}}$ & $\mathbf{K}_{\mathbf{2}}$ & $\mathbf{K}_{\mathbf{3}}$ & $\mathbf{K}_{\mathbf{4}}$ & Mean \\
\hline $\mathbf{N}_{\mathbf{1}}$ & 10.78 & 12.54 & 13.11 & 13.73 & $\mathbf{1 2 . 5 4}$ & 21.90 & 22.24 & 23.36 & 23.68 & $\mathbf{2 2 . 7 9}$ \\
\hline $\mathbf{N}_{\mathbf{2}}$ & 14.05 & 14.55 & 15.65 & 14.77 & $\mathbf{1 4 . 7 6}$ & 24.77 & 24.63 & 27.36 & 28.30 & $\mathbf{2 6 . 2 6}$ \\
\hline $\mathbf{N}_{\mathbf{3}}$ & 14.11 & 16.47 & 15.81 & 15.90 & $\mathbf{1 5 . 5 7}$ & 28.97 & 29.34 & 29.60 & 30.75 & $\mathbf{2 9 . 6 7}$ \\
\hline $\mathbf{N}_{\mathbf{4}}$ & 15.77 & 15.99 & 17.09 & 20.02 & $\mathbf{1 7 . 2 2}$ & 31.05 & 31.41 & 31.57 & 32.39 & $\mathbf{3 1 . 6 1}$ \\
\hline Mean & $\mathbf{1 3 . 6 8}$ & $\mathbf{1 4 . 8 9}$ & $\mathbf{1 5 . 4 2}$ & $\mathbf{1 6 . 1 1}$ & & $\mathbf{2 6 . 6 7}$ & $\mathbf{2 6 . 9 1}$ & $\mathbf{2 7 . 9 7}$ & $\mathbf{2 8 . 7 8}$ & \\
\hline & & $\mathbf{N}$ & $\mathbf{K}$ & $\mathbf{N} \times \mathbf{K}$ & $\mathbf{N}$ & $\mathbf{K}$ & $\mathbf{N} \times \mathbf{K}$ \\
\hline $\mathbf{S E m} \pm$ & 0.273 & 0.273 & 0.545 & 0.406 & 0.406 & 0.812 \\
\hline C.D. at 5\% & 0.788 & 0.788 & & 1.575 & 1.173 & 1.173 & NS \\
\hline
\end{tabular}

Table.5 Effect of nitrogen and potassium on root tuber dry matter content (\%) and root tuber yield per vine (g) in sweet potato (Ipomoea batatas Lam.)

\begin{tabular}{|c|c|c|c|c|c|c|c|c|c|c|}
\hline & \multicolumn{4}{|c|}{ Root tuber dry matter content (\%) } & \multicolumn{5}{c|}{ Root tuber yield per vine (g) } \\
\hline & $\mathbf{K}_{\mathbf{1}}$ & $\mathbf{K}_{\mathbf{2}}$ & $\mathbf{K}_{\mathbf{3}}$ & $\mathbf{K}_{\mathbf{4}}$ & $\mathbf{M e a n}$ & $\mathbf{K}_{\mathbf{1}}$ & $\mathbf{K}_{\mathbf{2}}$ & $\mathbf{K}_{\mathbf{3}}$ & $\mathbf{K}_{\mathbf{4}}$ & Mean \\
\hline $\mathbf{N}_{\mathbf{1}}$ & 24.25 & 24.79 & 25.44 & 25.52 & $\mathbf{2 5 . 0 0}$ & 134.07 & 122.22 & 133.87 & 147.36 & $\mathbf{1 3 4 . 3 8}$ \\
\hline $\mathbf{N}_{\mathbf{2}}$ & 26.13 & 26.24 & 26.53 & 26.48 & $\mathbf{2 6 . 3 5}$ & 189.44 & 231.63 & 241.60 & 247.02 & $\mathbf{2 2 7 . 4 2}$ \\
\hline $\mathbf{N}_{\mathbf{3}}$ & 26.83 & 26.93 & 27.37 & 27.96 & $\mathbf{2 7 . 2 7}$ & 255.42 & 279.91 & 312.11 & 330.82 & $\mathbf{2 9 4 . 5 7}$ \\
\hline $\mathbf{N}_{\mathbf{4}}$ & 28.47 & 29.20 & 30.44 & 32.17 & $\mathbf{3 0 . 0 7}$ & 341.76 & 348.32 & 389.10 & 445.98 & $\mathbf{3 8 1 . 2 9}$ \\
\hline Mean & $\mathbf{2 6 . 4 2}$ & $\mathbf{2 6 . 7 9}$ & $\mathbf{2 7 . 4 5}$ & $\mathbf{2 8 . 0 3}$ & & $\mathbf{2 3 0 . 1 7}$ & $\mathbf{2 4 5 . 5 2}$ & $\mathbf{2 6 9 . 1 7}$ & $\mathbf{2 9 2 . 7 9}$ & \\
\hline & & $\mathbf{N}$ & $\mathbf{K}$ & $\mathbf{N} \times \mathbf{K}$ & $\mathbf{N}$ & $\mathbf{N}$ & $\mathbf{K}$ & $\mathbf{N} \times \mathbf{K}$ \\
\hline SEm \pm & 0.404 & 0.404 & 0.808 & 4.626 & 4.626 & 9.253 \\
\hline C.D. at 5\% & 1.167 & 1.167 & NS & 13.362 & 13.362 & 26.724 \\
\hline
\end{tabular}


Table.6 Effect of nitrogen and potassium on root tuber yield per plot $(\mathrm{kg})$ and estimated root tuber yield per hectare $(\mathrm{t})$ in sweet potato (Ipomoea batatas Lam.)

\begin{tabular}{|c|c|c|c|c|c|c|c|c|c|c|}
\hline & \multicolumn{4}{|c|}{ Root tuber yield per plot (kg) } & \multicolumn{3}{c|}{ Estimated root tuber yield per hectare (t) } \\
\hline & $\mathbf{K}_{\mathbf{1}}$ & $\mathbf{K}_{\mathbf{2}}$ & $\mathbf{K}_{\mathbf{3}}$ & $\mathbf{K}_{\mathbf{4}}$ & $\mathbf{M e a n}$ & $\mathbf{K}_{\mathbf{1}}$ & $\mathbf{K}_{\mathbf{2}}$ & $\mathbf{K}_{\mathbf{3}}$ & $\mathbf{K}_{\mathbf{4}}$ & $\mathbf{M e a n}$ \\
\hline $\mathbf{N}_{\mathbf{1}}$ & 5.17 & 7.58 & 8.42 & 9.26 & $\mathbf{7 . 6 1}$ & 6.89 & 10.11 & 11.22 & 12.35 & $\mathbf{1 0 . 1 4}$ \\
\hline $\mathbf{N}_{\mathbf{2}}$ & 10.66 & 11.76 & 12.92 & 13.13 & $\mathbf{1 2 . 1 2}$ & 14.22 & 15.68 & 17.23 & 17.51 & $\mathbf{1 6 . 1 6}$ \\
\hline $\mathbf{N}_{\mathbf{3}}$ & 15.30 & 15.43 & 15.51 & 17.21 & $\mathbf{1 5 . 8 6}$ & 20.40 & 20.57 & 20.68 & 22.95 & $\mathbf{2 1 . 1 5}$ \\
\hline $\mathbf{N}_{\mathbf{4}}$ & 18.00 & 18.23 & 19.60 & 20.92 & $\mathbf{1 9 . 1 9}$ & 24.00 & 24.30 & 26.13 & 27.89 & $\mathbf{2 5 . 5 8}$ \\
\hline Mean & $\mathbf{1 2 . 2 8}$ & $\mathbf{1 3 . 2 5}$ & $\mathbf{1 4 . 1 1}$ & $\mathbf{1 5 . 1 3}$ & & $\mathbf{1 6 . 3 8}$ & $\mathbf{1 7 . 6 6}$ & $\mathbf{1 8 . 8 2}$ & $\mathbf{2 0 . 1 8}$ & \\
\hline & & $\mathbf{N}$ & $\mathbf{K}$ & $\mathbf{N} \times \mathbf{K}$ & $\mathbf{N}$ & $\mathbf{K}$ & $\mathbf{N} \times \mathbf{K}$ \\
\hline $\mathbf{S E m} \pm$ & 0.208 & 0.208 & 0.417 & 0.278 & 0.278 & 0.556 \\
\hline C.D. at 5\% & 0.602 & 0.602 & 1.204 & 0.803 & 0.803 & 1.605 \\
\hline
\end{tabular}

Table.7 Effect of nitrogen and potassium on beta Carotene (mg/100g f.w.) and starch content (\%) in sweet potato (Ipomoea batatas Lam.)

\begin{tabular}{|c|c|c|c|c|c|c|c|c|c|c|}
\hline & \multicolumn{4}{|c|}{ Beta Carotene (mg/100g f.w.) } & \multicolumn{5}{c|}{ Starch content (\%) } \\
\hline & $\mathbf{K}_{\mathbf{1}}$ & $\mathbf{K}_{\mathbf{2}}$ & $\mathbf{K}_{\mathbf{3}}$ & $\mathbf{K}_{\mathbf{4}}$ & $\mathbf{M e a n}$ & $\mathbf{K}_{\mathbf{1}}$ & $\mathbf{K}_{\mathbf{2}}$ & $\mathbf{K}_{\mathbf{3}}$ & $\mathbf{K}_{\mathbf{4}}$ & Mean \\
\hline $\mathbf{N}_{\mathbf{1}}$ & 9.45 & 9.61 & 9.85 & 10.53 & $\mathbf{9 . 8 6}$ & 12.32 & 14.77 & 15.87 & 16.95 & $\mathbf{1 4 . 9 8}$ \\
\hline $\mathbf{N}_{\mathbf{2}}$ & 10.28 & 10.43 & 10.74 & 11.67 & $\mathbf{1 0 . 7 8}$ & 11.17 & 11.84 & 13.94 & 14.64 & $\mathbf{1 2 . 9 0}$ \\
\hline $\mathbf{N}_{\mathbf{3}}$ & 11.68 & 11.84 & 12.00 & 12.33 & $\mathbf{1 1 . 9 6}$ & 10.69 & 11.51 & 13.84 & 13.93 & $\mathbf{1 2 . 4 9}$ \\
\hline $\mathbf{N}_{\mathbf{4}}$ & 12.37 & 12.44 & 12.52 & 12.92 & $\mathbf{1 2 . 5 6}$ & 10.28 & 10.82 & 12.17 & 13.25 & $\mathbf{1 1 . 6 3}$ \\
\hline Mean & $\mathbf{1 0 . 9 4}$ & $\mathbf{1 1 . 0 8}$ & $\mathbf{1 1 . 2 8}$ & $\mathbf{1 1 . 8 6}$ & & $\mathbf{1 1 . 1 1}$ & $\mathbf{1 2 . 2 4}$ & $\mathbf{1 3 . 9 5}$ & $\mathbf{1 4 . 6 9}$ & \\
\hline & & $\mathbf{N}$ & $\mathbf{K}$ & $\mathbf{N} \times \mathbf{K}$ & $\mathbf{N}$ & $\mathbf{K}$ & $\mathbf{N} \times \mathbf{K}$ \\
\hline $\mathbf{S E m} \pm$ & 0.061 & 0.061 & 0.121 & 0.140 & 0.140 & 0.280 \\
\hline C.D. at 5\% & 0.175 & 0.175 & 0.350 & 0.404 & 0.404 & 0.808 \\
\hline
\end{tabular}

Table.8 Effect of nitrogen and potassium on reducing sugars (\%) and non-reducing sugars (\%) in sweet potato (Ipomoea batatas Lam.)

\begin{tabular}{|c|c|c|c|c|c|c|c|c|c|c|}
\hline & \multicolumn{9}{|c|}{ Reducing sugars (\%) } & \multicolumn{4}{c|}{ Non-reducing sugars (\%) } \\
\hline & $\mathbf{K}_{\mathbf{1}}$ & $\mathbf{K}_{\mathbf{2}}$ & $\mathbf{K}_{\mathbf{3}}$ & $\mathbf{K}_{\mathbf{4}}$ & $\mathbf{M e a n}$ & $\mathbf{K}_{\mathbf{1}}$ & $\mathbf{K}_{\mathbf{2}}$ & $\mathbf{K}_{\mathbf{3}}$ & $\mathbf{K}_{\mathbf{4}}$ & Mean \\
\hline $\mathbf{N}_{\mathbf{1}}$ & 3.66 & 3.87 & 3.62 & 3.69 & $\mathbf{3 . 7 1}$ & 0.56 & 0.48 & 0.65 & 0.74 & $\mathbf{0 . 6 2}$ \\
\hline $\mathbf{N}_{\mathbf{2}}$ & 3.64 & 3.75 & 3.78 & 3.72 & $\mathbf{3 . 7 2}$ & 0.71 & 0.56 & 0.75 & 0.83 & $\mathbf{0 . 7 1}$ \\
\hline $\mathbf{N}_{\mathbf{3}}$ & 3.84 & 3.87 & 3.94 & 3.87 & $\mathbf{3 . 8 8}$ & 0.67 & 0.72 & 0.76 & 0.85 & $\mathbf{0 . 7 5}$ \\
\hline $\mathbf{N}_{\mathbf{4}}$ & 3.88 & 3.86 & 3.79 & 3.96 & $\mathbf{3 . 8 7}$ & 0.72 & 0.69 & 0.86 & 0.90 & $\mathbf{0 . 7 9}$ \\
\hline Mean & $\mathbf{3 . 7 5}$ & $\mathbf{3 . 8 4}$ & $\mathbf{3 . 7 8}$ & $\mathbf{3 . 8 1}$ & & $\mathbf{0 . 6 7}$ & $\mathbf{0 . 6 3}$ & $\mathbf{0 . 7 6}$ & $\mathbf{0 . 8 3}$ & \\
\hline & & $\mathbf{N}$ & $\mathbf{K}$ & $\mathbf{N} \times \mathbf{K}$ & $\mathbf{N}$ & $\mathbf{K}$ & $\mathbf{N} \times \mathbf{K}$ \\
\hline $\mathbf{S E m} \pm$ & 0.038 & 0.038 & 0.075 & 0.022 & 0.022 & 0.044 \\
\hline C.D. at 5\% & 0.109 & NS & & NS & 0.064 & 0.064 & NS \\
\hline
\end{tabular}


Table.9 Effect of nitrogen and potassium on total sugars (\%) in sweet potato (Ipomoea batatas Lam.)

\begin{tabular}{|c|c|c|c|c|c|}
\hline & \multicolumn{5}{|c|}{ Total Sugars (\%) } \\
\hline & $\mathbf{K}_{\mathbf{1}}$ & $\mathbf{K}_{\mathbf{2}}$ & $\mathbf{K}_{\mathbf{3}}$ & $\mathbf{K}_{\mathbf{4}}$ & Mean \\
\hline $\mathbf{N}_{\mathbf{1}}$ & 4.22 & 4.42 & 4.27 & 4.42 & $\mathbf{4 . 3 3}$ \\
\hline $\mathbf{N}_{\mathbf{2}}$ & 4.35 & 4.31 & 4.54 & 4.55 & $\mathbf{4 . 4 4}$ \\
\hline $\mathbf{N}_{\mathbf{3}}$ & 4.51 & 4.59 & 4.70 & 4.73 & $\mathbf{4 . 6 3}$ \\
\hline $\mathbf{N}_{\mathbf{4}}$ & 4.60 & 4.55 & 4.65 & 4.86 & $\mathbf{4 . 6 7}$ \\
\hline Mean & $\mathbf{4 . 4 2}$ & $\mathbf{4 . 4 7}$ & $\mathbf{4 . 5 4}$ & $\mathbf{4 . 6 4}$ & \\
\hline & & $\mathbf{N}$ & $\mathbf{K}$ & & $\mathbf{N} \times \mathbf{K}$ \\
\hline $\mathbf{S E m} \pm$ & & 0.036 & 0.036 & & 0.071 \\
\hline C.D. at 5\% & & 0.103 & 0.103 & & NS \\
\hline
\end{tabular}

The Reducing sugars and non-reducing sugars increase with increase in the sugar content in tubers. This might be due to association exists between uptake and accumulation of nutrient in tuber and also between their combined role in enhancing the synthesis of sucrose content and accumulation in tubers. The similar results were found by Patil et al., (1990) in sweet potato. Mehran and Samad (2013) observed that, the nitrogen significantly increased sucrose contents, recoverable sugar yield adding to the highest level of nitrogen in sugar beet crop.

Application of higher levels of fertilizer in turn leads to increase in vegetative growth and higher photosynthates accumulation and metabolism in plants. This might be the reason for increased biosynthesis of pigments and antioxidants. The findings are in conformity with Ali et al., (2013) in carrot. From the results obtained in the present investigation, it can be concluded that the application of $120 \mathrm{~kg}$ nitrogen $\mathrm{ha}^{-1}$ and $120 \mathrm{~kg}$ potassium $\mathrm{ha}^{-1}$ proved to be best for cultivation of sweet potato in light soils of coastal Andhra Pradesh for getting highest economic yield.

\section{Acknowledgement}

The work was supported by department of vegetable Science, College of Horticulture, Venkataramannagudem, West Godavari (AP), India. I am thankful to Dr. Kranti Rekha, and Mr. Sekhar, for their assistance in the completion of this research work.

\section{References}

Ali, M.A, Hossain, M.A. Mondal, M.F. and Farooque, A.M. 2013. Effect of nitrogen and potassium on yield and quality of carrot.Pakistan Journal of Biological Sciences. 6(18): 1574-77.

Bansal, S.K. and Trehan, S.P. 2011. Effect of potassium on yield and processing quality attributes of potato. Karnataka Journal of Agricultural Science.24 (1): 48-54.

Bishnu, H, Adhikary and Krishna B.K. 2006.Effect of potassium on potato tuber production in acid soils of malepatan, Pokhara.Nepal AgricultureResearch Journal. Vol. 7.

Gupta, A. and Saxena, M. C. 1976. Dry matter and nitrogen accumulation in different plant parts of potato in relation to soil fertility. Indian Journal of Agriculture Science. 46(1): 541-45.

Hukkeri, S.B. 1968. Effect of nitrogen, phosphorous and potash on the yield and quality of potato.Indian Journal of Agriculture Science. 38 (5): 845-849. 
Imran, S.M, Sattar, M.A, Islam, M.R, Hossain, M.M.A. and Alam, M.S. 2010. Effect of different organic and inorganic fertilizers on growth and yield of mukhikachu (Colocasia esculenta) cv. Salikachu. Journal of Agroforestry and Environment.4(2): 53-56.

Jones, A. 1965.A proposed breeding procedure for sweet potato. Crop Science. 5: 191-92.

Leilah, A.A, Badawi, M.A, Said, E.M, Ghonema, M.H. and Abdou, M.A.E. 2005.Effect of planting dates, plant population and nitrogen fertilization on sugar beet productivity under the newly reclaimed sandy soils. Scientific Journal of King Faisal University. 6 (1): 95-109.

Marton, L. 2010. Potassium effects on potato (Solanum tuberosum L.) yield. Journal of Potassium.1(4): 89-92.

Mehran, S. and Samad, S. 2013.Study of potassium and nitrogen fertilizer levels on the yield of sugar beet in jolge cultivar. Journal Novel Applied Science. 2(4): 94-100.

Narasareddy, S. and Suryanarayana, R. 1968.Response of potato to different levels of nitrogen, phosphorous and potash on sandy loam soil of Hyderabad.Indian Journal of
Agriculture Science. 38(3): 577-84.

Padmanabhan, V, Dsaradhi, T.B. and Khanna, S. 1975. Performance of hybrid Sweet potato variety $\mathrm{H}-66$ at different levels of nitrogen and in different seasons under Hydrabad condition. First National Symposium on root crops. Journal of Root Crops. 1(2): 94-95.

Patil, Y.B, Patil, A.A, Hilmani, N.C, and Patil, V.S. 1990. Influence of varying levels of nitrogen, potassium and interrow spacing on certain quality attributes of sweet potato. Karnataka Journal of Agricultural Science.3(3 \& 4): 281-85.

Rajendrann, Mohankumar, B. and Nair P.G. 1971. Nutritional uptake studies in tuber crops. Annual Report 1970.CTCRI, Trivadrum, India. pp. 1-52.

Selim, E.M, Elsirafy, Z.M. and Taha, A.A. 2010. Effect of irrigation methods and applications on the utilization of nitrogen by sugar beet grown under arid condition.Australian Journal of Basic and Applied Sciences. 4(7): 2114-24.

Uwah, D.F, Afonne, F.A. and Essien, A.R. 2013. Integrated nutrient management for Cassava production in Calabar, Nigeria. Australian Journal of Basic Applied Sciences.5(11): 1019-25.

\section{How to cite this article:}

Sharath. S. R, M. Janaki, K. Uma Jyothi and Uma Krishna. K. 2020. Effect of Nitrogen and Potassium on Growth, Yield and Quality of Orange Fleshed Sweet Potato (Ipomoea batatas Lam. ). Int.J.Curr.Microbiol.App.Sci. 9(03): 178-191. doi: https://doi.org/10.20546/ijcmas.2020.903.022 